\section{Luciene Petcov Machado'}

Maria Beatriz Junqueira

Camargo"

José Carlos Milanez Jeronymo"I'

Gisele Alsina Nader Bastos'II
Curso de Especialização Saúde da Família. Escola de Gestão em Saúde. Hospital Moinhos de Vento. Porto Alegre, RS, Brasil

" Programa de Pós-Graduação em Epidemiologia. Universidade Federal de Pelotas. Pelotas, RS, Brasil

III Associação Hospitalar Moinhos de Vento. Porto Alegre, RS, Brasil

\section{Correspondence:}

Luciene Petcov Machado

R. Antonio Francisco Fonseca,30

Centro

94010-340 Gravataí, RS, Brasil

E-mail: petcovm@terra.com.br

\section{Regular use of dental services among adults and older adults in a vulnerable region in Southern Brazil}

\begin{abstract}
OBJECTIVE: To estimate the prevalence of regular use of dental care services by adults and older adults residing in vulnerable community and to identify associated factors.
\end{abstract}

METHODS: A population-based cross-sectional study was carried out with 3,391 adults and older adults residing in areas of social vulnerability in Porto Alegre, Southern Brazil, from July to December of 2009. A systematic sampling method was used the selection probability proportional to the population of each of the the 121 census sectors. The outcome for regular use of dental care services was defined as regular use of dental services, regardless of the presence of dental problems. A standardized questionnaire was administered, which included demographic, socioeconomic, type of dental care services, selfperception of dental health and self-perceived needs variables. A chi-square test for heterogeneity was used for bivariate analyses, and a Poisson regression with a robust variance and Wald tests were performed for the adjusted analysis.

RESULTS: The prevalence of regular use of dental services was $25.7 \%$. The prevalence was higher among people with $\geq 12$ years schooling (PR 2.48 [95\%CI:1.96;3.15]), higher income (PR 1.95[95\%CI: 1.03;1.53]), use of private health services (PR 1.43 [95\%CI: 1.20;1.71]),excellent self-perceived oral health (PR 4.44 [95\%CI: 3.07;6.42]) and a self-perceived need for consultation related to routine checkup (RP 2.13 [95\%CI: 1,54;2,96]).

CONCLUSIONS: Inequalities were found in the regular use of dental services. Integrated approaches that raise awareness of oral health, improve self-care and expand access to dental services, may contribute to increase the use of dental services on a regular basis.

\section{DESCRIPTORS: Vulnerable Populations. Dental Care, utilization. Oral Health. Cross-Sectional Studies.}

\section{INTRODUCTION}

Brazil is undergoing a transition from curative and surgical dental services where access was restricted to different population groups to dental services that focus on prevention and equitable access to health. ${ }^{15}$ The reorganization of care ensures the quality of services offered, while strengthening health education, preventative measures and the importance of self-care. The National Oral Health Policy (Smiling Brazil [Brasil Sorridente]) a proposes a reorganization

\footnotetext{
a Ministério da Saúde (BR). Secretaria de Atenção à Saúde. Departamento de Atenção Básica. Coordenação de Saúde Bucal. Diretrizes da Política Nacional de Saúde Bucal. Brasília; 2004[cited 2012 Mar 9]. Available from: http://conselho.saude.gov.br/web_comissoes/cisb/doc/ politica_nacional.pdf
} 
of care for oral health with an emphasis on the action of health promotion, prevention and recuperation of oral health for all Brazilians, based on the principles and rights of the Sistema Único de Saúde (SUS - National Unified Health System).

The Ministry of Health performed an epidemiologic study across the entire country in 2003, called the Brazil Oral Health Project (Projeto de Saúde Bucal Brasil, $\mathrm{SB}){ }^{\mathrm{b}}$ In the previous year, the proportion performing a visit was 37\% among adults and 17\% among older adults. When asked about the reason for the visit, $26 \%$ of adults and $18 \%$ of older adults reported a routine visit, i.e. the prevalence of routine use of dental services decreases with age.

Studies show a beneficial association between regular use of dental services and better oral health. ${ }^{1,6,12}$ This use creates constant contact between the patient and health provider, contributes to increased knowledge of oral health, improved self-care allows for early identification of dental problems, facilitating recuperation. ${ }^{6}$

A birth cohort study found that young adults, who were classified as regular users, presented a self-perception of oral health as "better than average," less teeth with caries and less dental loss due to caries, ${ }^{18}$ even after controlling for sex, socioeconomic stats and a plaque index.

Brazilian population based studies analyzed the prevalence of regular use of dental services by adults and older adults in a small city of Minas Gerais state (southeastern Brazil, 24.6\%) ${ }^{10}$ and in a medium size city of Rio Grande do Sul state (southern, 3.8\%). ${ }^{4}$ Higher education, greater income, younger age and not having a partner were associated with regular use of these services. Individuals that manifested favorable opinions of dentists, that preferred conservative treatment and that received guidance about prevention had a higher prevalence of regular use. , $^{40}$

Considering the limited literature in Brazil about routine use and oral health benefits, this study aimed to estimate the prevalence of regular use of dental services among adults and older adults in areas of social vulnerability and to identify associated factors.

\section{METHODS}

A cross-sectional population base study was performed with 3,391 adults and older adults in areas of social vulnerability in Porto Alegre, southern Brazil, from July to December of 2009. Porto Alegre had approximately 1,420,667 residents across 110 neighborhoods. In the Public Health Districts of Restinga and Extreme South, located in the southern zone of the city, have approximately 90,000 residents according to the 2000 Census. ${ }^{c}$ These districts were officially created in 1990, although there were unorganized settlements, since the 1960s, by people from lower social strata. Located $22 \mathrm{~km}$ from the central areas, they only have primary health services and one urgent care clinic. According to the report about the Indicators of Multidimensional Poverty and Extreme Poverty for Porto Alegre from 2007, ${ }^{\mathrm{d}}$ the region of Restinga was characterized as one of the poorest regions in the city per the multidimensional view and is the region with the highest levels of unmet need for health, employment and income. The Multidimensional Index of Needs was constructed for this analysis, in which poverty is conceptualized and measured as a process of multiple needs, which includes the spheres of health, employment, income, education and housing, instead of a simply measurement of income insufficiency. In the region of Restinga, $45.4 \%$ of the interviewees lived in extreme poverty, conceptualized as severe deprivation of hunger, cold and housing.

The Hospital Association Moinhos de Vento, in partnership with the Ministry of Health, performed this epidemiology survey to describe demographic and socioeconomic characteristics of these population and to evaluate the health of the community and access and use of medical and dental services.

A count of houses in each census sector was performed because of possible changes since the 2000 Census. Of the 121 census sectors, 117 were included. The count identified 32,067 houses and commercial establishments, of which 29,929 were inhabited. Considering estimates for different outcomes, 1,750 places of residence were randomly selected. Residents age 20 years or older and able to answer the questionnaire were included, for a total of 3,700 adults and older persons.

The parameters used to calculate sample size were: a $25 \%$ prevalence in the regular use of dental services, a $95 \%$ confidence interval and acceptable error of $2 \%$, with an additional $10 \%$ for potential losses and refusals and $15 \%$ for potential confounding factors, resulting in a total of 2,238 individuals.

Previously trained interviewers administered the standardized and pre-coded questionnaire that contains

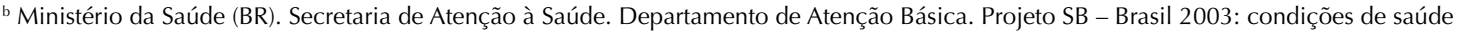
bucal da população brasileira 2002-2003. Resultados principais. Brasília; 2005[cited 2012 Mar 9].(Série C. Projetos, Programas e Relatórios). Available from: http://dtr2001.saude.gov.br/editora/produtos/livros/pdf/05_0053_M.pdf

c Instituto Brasileiro de Geografia e Estatística. Dados do Censo 2010 publicados no Diário Oficial da União do dia 04/11/2010. Brasília; 2010 [cited 2011 Dec 10]. Available from: http://www.censo2010.ibge.gov.br/dados_divulgados/index.php

${ }^{d}$ Comim FG, Bagolin IP, Porto Jr SS, Bender Filho R, Picolotto V, Avila RP. Relatório sobre indicadores de pobreza multidimensional e pobreza extrema para Porto Alegre. Porto Alegre: Universidade Federal do Rio Grande do Sul; 2007 [cited 2011 Dec 10]. Available from: http://lproweb.procempa.com.br/pmpa/prefpoa/observatorio/usu_doc/pobreza_multi.pdf
} 
180 questions about demographics, socioeconomic stats and health status. A sub-sample of $10 \%$ of the interviews was randomly selected and responses were verified by supervisors through telephone re-interview, to assure data quality. An individual was considered as a sampling loss if they were not encountered after two visits at different days and times that the interviewers alternated and one visit pre-scheduled by the field supervisor. For categorization as a refusal there were at least three attempts to interview and a negative response by the individuals. The response rate was $91.6 \%$ for a total of 3,391 individuals interviewed.

After review, the questionnaires were digitized used the software Office Remark ${ }^{\circledR}$ (Gravic Inc, Philadelphia, USA) with automatic checking for inconsistencies.

The interviewees were provided four options to describe the routine nature of their visits in order to obtain the outcome $^{5}$ (regular use of dental services): (1) I never go to the dentist; (2) I go to the dentist when I have pain or have a problem with my teeth or gums; (2) I go to the dentist sometimes, if I have or do not have a problem; (4) I go to the dentist regularly. People that selected option three or four were considered regular users.

The proximity of determinants was established using the various exposure variables that could influence the regular use of dental services. Demographic variables were considered as distal: sex, age (completed years), self-reported skin color and socioeconomic factors represented by schooling (completed years) and economic level categorized as income quintiles. Variables for self-perception of oral health and type of service normally accessed constituted the intermediate level. The categories for health insurance and private payment were grouped as the private sector, since payment is made in both cases. The most proximal level consisted of the self-perceived need for treatment (need to go to the dentist) categorized by four statements: "yes, to perform a check-up"; "no, everything is fine with my teeth"; "yes, I have pain or have a problem to resolve"; "no, I have a problem, but it can wait".

The bivariate analysis for the regular use of dental services was tests using the chi-square test for heterogeneity. The adjusted analysis use Poisson regression robust variance and the Wald test for heterogeneity. Data analysis was performed with the STATA 9.0 program.

The study was approved by the Committee for Ethics and Human Research of Moinhos de Vento Hospital Association (protocol 2009/28). The participants provided their written consent and received a guarantee of non-disclosure and were informed of their right to withdraw at any point, without repercussions for them or their family.

\section{RESULTS}

The prevalence of regular use of dental services was $25.7 \%$ (95\%CI: 24.2;27.2).

The majority were young adults (between 20 and 39 years), with an average age of 44.1 years, white skin, female sex, and less than nine years of educational attainment (Table 1).

The prevalence of regular use of dental services was inversely proportional to the increase in age. The prevalence of regular use of private services was approximately twice the prevalence for the public sector. Self-perception of very good/good oral health was reported by $56.7 \%$ of the sample, and $10.6 \%$ of people reported poor/very poor oral health. The prevalence of regular use was $52.2 \%$ among those that reported the perception of very good oral health and $8.4 \%$ among those that reported poor/very poor (Table 1 ).

In crude analysis, all the characteristics presented a statistically significant association with the regular use of dental services, with the exception of skin color (Table 1).

The age variable lost statistical significance in the multiple analysis, according to the conceptual model (Table 2). Women used the dental services approximately $30.0 \%$ more than men. Prevalence was 1.91 higher among individuals with nine to 11 years of schooling and 2.48 higher more individuals with more than 12 years, when compared to those who had four or less years of schooling.

Individuals that belonged to the richer income quintiles had a greater prevalence of regular use compared to the poorest quintile, even after controlling for the other variables in the more distal level.

Regular use was $43.0 \%$ greater in private institutions than in public institutions (Table 2).

The variable most strongly associated with the regular use of dental services was self-perception of oral health. Individuals that reported very good health had a prevalence of regular use 4.4 times greater compared to individuals that reported poor/very poor oral health (Table 2).

Individuals that reported not needing treatment or that only needed a regular check-up utilized dental services approximately two times more than individuals than individuals who reported a problem that could wait (Table 2).

\section{DISCUSSION}

The prevalence of regular use of dental services was $25.7 \%$ and is in accordance with the limited national literature. Camargo et $\mathrm{al}^{4}(2009)$ and Matos et al ${ }^{10}$ (2001) found prevalences of regular visits of $32.8 \%$ and 
Table 1. Sample distribution, prevalences and crude prevalence ratios for the regular use of dental services among the categories of independent variables. Restinga and Extremo-Sul Public Health Districts, Porto Alegre, Southern Brazil, 2009.

\begin{tabular}{|c|c|c|c|c|c|}
\hline Variable & $\mathrm{n}$ & $\%$ & $\begin{array}{l}\text { Prevalence of } \\
\text { regular use \% }\end{array}$ & $\begin{array}{c}\text { PR } \\
(95 \% \mathrm{Cl})\end{array}$ & $p^{*}$ \\
\hline Sex & 2,961 & & & & $<0.001$ \\
\hline Male & 1,496 & 44.1 & 22.3 & 1 & \\
\hline Female & 1,895 & 55.9 & 28.4 & $1.27(1.13 ; 1.43)$ & \\
\hline Age & 2,961 & & & & $<0.001$ \\
\hline From 20 to 39 years & 1,440 & 42.5 & 38.7 & $1.67(1.38 ; 2.01)$ & \\
\hline From 40 to 59 years & 1,313 & 38.7 & 26.7 & $1.55(1.28 ; 1.87)$ & \\
\hline 60 or more years & 638 & 18.8 & 17.2 & 1 & \\
\hline Skin color & 2.957 & & & & 0.75 \\
\hline White & 2,636 & 77.7 & 25.9 & 1 & \\
\hline Not white & 755 & 22.3 & 25.3 & $0.98(0.85 ; 1.12)$ & \\
\hline Schooling & 2,960 & & & & $<0.001$ * * \\
\hline 4 or less years & 565 & 17.7 & 17.0 & 1 & \\
\hline 5 to 8 years & 1,279 & 40.2 & 19.4 & $1.14(0.92 ; 1.41)$ & \\
\hline 9 to 11 years & 1,053 & 33.1 & 34.7 & $2.04(1.67 ; 2.49)$ & \\
\hline$>12$ years & 288 & 9.0 & 46.9 & $2.76(2.21 ; 3.44)$ & \\
\hline Income quintiles & & & & & $<0.001$ * * \\
\hline 1 - lowest & 679 & 20.0 & 19.3 & 1 & \\
\hline 2 & 683 & 20.1 & 21.5 & $1.12(0.90 ; 1.38)$ & \\
\hline 3 & 680 & 20.1 & 27.9 & $1.45(1.19 ; 1.76)$ & \\
\hline 4 & 681 & 20.1 & 28.8 & $1.49(1.23 ; 1.81)$ & \\
\hline 5 - highest & 668 & 19.7 & 31.3 & $1.62(1.34 ; 1.58)$ & \\
\hline Type of service used & 2,890 & & & & $<0.001$ \\
\hline Public & 811 & 25.6 & 16.0 & 1 & \\
\hline Private & 2,358 & 74.4 & 31.5 & $1.96(1.66 ; 2.32)$ & \\
\hline Self-perception of oral health & 2.961 & & & & $<0.001$ \\
\hline Very good & 245 & 7.2 & 52.2 & $6.25(4.35 ; 8.99)$ & \\
\hline Good & 1,678 & 49.5 & 30.3 & $3.62(2.55 ; 5.14)$ & \\
\hline Fair & 1,106 & 32.6 & 18.7 & $2.24(1.56 ; 3.22)$ & \\
\hline Poor/very poor & 359 & 10.6 & 8.4 & 1 & \\
\hline In need ofr treatment & 2.959 & & & & $<0.001$ \\
\hline Yes, for check-up & 1,167 & 34.6 & 30.0 & $2.53(1.81 ; 3.52)$ & \\
\hline No, things are okay & 1,262 & 37.4 & 30.8 & $2.60(1.87 ; 3.61)$ & \\
\hline Yes, I have problems & 668 & 19.8 & 15.1 & $1.27(0.88 ; 1.84)$ & \\
\hline No, it can wait & 278 & 8.2 & 11.9 & 1 & \\
\hline
\end{tabular}

* Chi-square test for heterogeneity

** Test for linear trend

$24.6 \%$ respectively, similar to the present study. This is likely due to the similarities in the educational level of the samples, since greater education is associated with utilization. In the population survey SB Brasil $2003,37 \%$ of Brazilian adults performed routine visits. Nonetheless, comparisons between studies should be done with caution due to differences in the criteria used to define regular users, in the cultural and socioeconomic characteristics of the populations studied and in the organization of services. ${ }^{13}$
Women perform more regular consultations, according to a Canadian study with low-income women, as also in the present study. In a context of poverty, men have long commutes to work, often far from their residence, which may limit their availability to access dental care. ${ }^{11}$ In addition, women present greater concern with health and self-care than men. Baldani et $a^{3}{ }^{3}$ (2010) suggest that older people tend to decrease dental visits as they age due to the high prevalence tooth loss and due to difficulty in access which barriers from includes scarce 
Table 2. Multiple regression analysis according to the conceptual model for the regular use of dental services among adults, according to distal, intermediate and proximate factors. Restinga Extremo-Sul Public Health Districts, Porto Alegre, Southern Brazil, 2009. $(\mathrm{n}=3,391)$

\begin{tabular}{|c|c|c|c|}
\hline Level & Variable & PR $(95 \% \mathrm{Cl})$ & $\mathrm{p}^{*}$ \\
\hline \multirow[t]{3}{*}{$1^{\mathrm{a}}$} & Sex & & $<0.001$ \\
\hline & Male & 1 & \\
\hline & Female & $1.29(1.15 ; 1.45)$ & \\
\hline \multirow[t]{4}{*}{$1^{\mathrm{a}}$} & Age (years) & & 0.08 \\
\hline & 20 to 39 & $1.17(0.96 ; 1.43)$ & \\
\hline & 40 to 59 & $1.24(1.02 ; 1.52)$ & \\
\hline & $\geq 60$ & 1 & \\
\hline \multirow[t]{5}{*}{$1^{\mathrm{a}}$} & Schooling (years) & & $<0.001$ \\
\hline & 0 to 4 & 1 & \\
\hline & 5 to 8 & $1.12(0.90 ; 1.39)$ & \\
\hline & 9 to 11 & $1.91(1.54 ; 2.37)$ & \\
\hline & $\geq 12$ & $2.48(1.96 ; 3.15)$ & \\
\hline \multirow[t]{6}{*}{$1^{\mathrm{a}}$} & Income quintiles & & 0.01 \\
\hline & 1 - lowest & 1 & \\
\hline & 2 & $1.04(0.85 ; 1.29)$ & \\
\hline & 3 & $1.33(1.09 ; 1.62)$ & \\
\hline & 4 & $1.28(1.05 ; 1.55)$ & \\
\hline & 5 - highest & $1.95(1.03 ; 1.53)$ & \\
\hline \multirow[t]{3}{*}{$2^{a}$} & $\begin{array}{l}\text { Type of service } \\
\text { used }\end{array}$ & & $<0.001$ \\
\hline & Public & 1 & \\
\hline & Private & $1.43(1.20 ; 1.71)$ & \\
\hline \multirow[t]{5}{*}{$2^{a}$} & $\begin{array}{l}\text { Self-perception of } \\
\text { oral health }\end{array}$ & & $<0.001$ \\
\hline & Very good & $4.44(3.07 ; 6.42)$ & \\
\hline & Good & $2.94(2.06 ; 4.19)$ & \\
\hline & Fair & $1.90(1.32 ; 2.75)$ & \\
\hline & Poor/Very poor & 1 & \\
\hline \multirow[t]{5}{*}{$3^{a}$} & $\begin{array}{l}\text { Self-perception of } \\
\text { need for treatment }\end{array}$ & & $<0.001$ \\
\hline & $\begin{array}{l}\text { Yes, for a check- } \\
\text { up }\end{array}$ & $2.13(1.54 ; 2.96)$ & \\
\hline & $\begin{array}{l}\text { No, things are } \\
\text { okay }\end{array}$ & $2.01(1.44 ; 2.79)$ & \\
\hline & $\begin{array}{l}\text { Yes, I have } \\
\text { problems }\end{array}$ & $1.41(0.98 ; 2.01)$ & \\
\hline & $\mathrm{No}$, it can wait & 1 & \\
\hline
\end{tabular}

*Wald test for heterogeneity

a Variables adjusted for other variables at the same level and from the levels above.

supply of dental care services to barriers such as motorphysical difficulties of these individuals. The belief that dental visits are not necessary for toothless individuals and that tooth loss is part of a natural process of aging both contribute to reduced regular visits. ${ }^{9,10,13,17}$ Age lost statistical significance after adjustment for education in the present study. The effect of education can have a more importance role than age on the outcome since it leads to greater knowledge of oral health and understanding of the importance of using preventative health services.

The population of highest income quintile and greatest education had a higher prevalence of regular use of dental services compared to poorer and less educated women, similar to other studies. ${ }^{4,10}$ The association of income and education with the outcome may have different meanings. Greater income may facilitate the purchase of a service and education may bring information about the importance of regular use of dental health services.

The association between improved self-perception of oral health and greater regular use of services was observed by other studies. ${ }^{1,4,10}$ In contrast to Matos et $\mathrm{al}^{10}$ (2001) and in agreement with Camargo et $\mathrm{al}^{4}$ (2009), the self-perception of a need for treatment was measured in four levels by the present study. Those that responded "not having a needs because everything was fine" or that "yes, for a checkup" had higher prevalence of regular use compared to individuals that said "despite having a problem to resolve, they could wait". The search for resolution of a perceived problem was not associated with the regular use of dental services, a result similar to observed by other researchers. ${ }^{7,16}$ To measure self-perception of the need of treatment in this manner can increase the explanatory power when compared to the most common method, which dichotomized the response as "yes" or "no". ${ }^{7}$

The highest prevalence of regular use of dental services was among those that used private services, as also observed in Pelotas, southern Brazil. ${ }^{4}$ A study about the characteristics associated with the public sector identified the feeling of pain as a strong predictor for use. ${ }^{14}$ Among regular users, this behavior is not common, which may in part explain the greater prevalence of regular use in the private services. ${ }^{8}$

The ratio of dentists/population is $1 / 15,000$, an unfavorable ratio. The repressed demand in the adult and older adult population is large. Breaking with the traditional model of service organization, which prioritized urgent care for the adult population, and reorganizing work processes in order to include health prevention and promotion actions without negatively impacting care for the population constitutes a challenge for dental health services. This new model of care could increase access and regular use of dental services. ${ }^{2}$

Complementary analyses identified that $73.5 \%$ of individuals reported not having any type of medical insurance and $6.6 \%$ reported performing a medical visit in a private clinic during the previous three months. This 
suggests that this is a region where a large percentage of individuals depend exclusively on the public sector. Therefore, increased supply of public dental services can have a large impact on the oral health of this population. The expansion of supply in dental services, with incentives for regular utilization, can lead to improved knowledge about the health and illness process, increase the early diagnosis of oral problems and decrease the resulting loss of teeth from untreated caries.

Among the limitations, the study used a cross-sectional design, which allows for the generation of hypothesis about the associations identified. The outcome generated by self-report may lead to overestimation of regular use, since this behavior is socially desirable. This limitation is possible in all population surveys in which information is obtained by self-report. Nonetheless, the present study had a high response rate and a representative sample of the region, which strengthens its internal validity.

Inequalities were found in the regular use of dental services. Women of greater education, higher income and better self-perception of oral health had higher prevalence of utilization when compared to less educated and poorer men. Having a better perception of oral health and self-perception of a need of treatment to perform a check-up were associated with higher prevalence of regular use in comparison to people with a perceived oral health as poor/very poor and that had a problem but could wait.

Actions that contribute to increased knowledge of oral health and improved self-care, while also increasing access to dental services in an integrated approach, can contribute to increasing the regular use of dental services. 


\section{REFERENCES}

1. Afonso-Souza G, Nadanovsky P, Chor D, Faerstein E, Werneck GL, Lopes CS. Association between routine visits for dental checkup and self-perceived oral health in an adult population in Rio de Janeiro: the Pró-Saúde Study. Community Dent Oral Epidemiol. 2007;35(5):393-400. DOI:10.1111/j.16000528.2006.00343.x

2. Antunes JLF, Narvai PC. Políticas de saúde bucal no Brasil e seu impacto sobre as desigualdades em saúde. Rev Saude Publica. 2010;44(2):360-5. DOI:10.1590/ S0034-89102010005000002

3. Baldani $\mathrm{MH}$, Brito WH, Lawder JAC, Mendes YBE, Silva FFM, Antunes JLF. Determinantes individuais da utilização de serviços odontológicos por adultos e idosos de baixa renda. Rev Bras Epidemiol. 2010;13(1):150-62. DOI:10.1590/S1415790X2010000100014

4. Camargo MB, Dumith SC, Barros AJD. Uso regular de serviços odontológicos entre adultos: padrões de utilização e tipos de serviços. Cad Saude Publica. 2009;25(9):1894-906. DOI:10.1590/S0102311X2009000900004

5. Gilbert GH, Duncan RP, Heft MW, Coward RT. Dental Health attitudes among dentate black and white adults. Med Care. 1997;35(3):255-71. DOI:10.1097/00005650-199703000-00006

6. Gilbert GH, Stoller EP, Duncan RP, Earls JL, Campbell AM. Dental self-care among dentate adults: contrasting problem-oriented dental attenders and regular dental attenders. Spec Care Dentist. 2000;20(4):155-63. DOI:10.1111/j.1754-4505.2000.tb01153.x

7. Heft MW, Gilbert GH, Shelton BJ, Duncan RP. Relationship of dental status, sociodemographic status and oral symptoms to perceived need for dental care. Community Dent Oral Epidemiol. 2003;31(5):351-60. DOI:10.1034/j.1600-0528.2003.00014.x

8. Lacerda JT, Simionato EM, Peres KG, Peres MA, Traebert J, Marcenes W. Dor de origem dental como motivo de consulta odontológica em uma população adulta. Rev Saude Publica. 2004;38(3):453-8. DOI:10.1590/S0034-89102004000300017

9. Martins AM, Haikal DS, Pereira SM, Barreto SM. Uso de serviços odontológicos por rotina entre idosos brasileiros: Projeto SB Brasil. Cad Saude Publica. 2008;24(7):1651-66. DOI: 10.1590/S0102311X2008000700020

10. Matos DV, Lima-Costa MFF, Guerra HI, Marcenes W. Projeto Bambuí: estudo de base populacional dos fatores associados com o uso regular de serviços odontológicos em adultos. Cad Saude Publica. 2001;17(3):661-8. DOI:10.1590/S0102311X2001000300020

11. Muirhead VE, Quiñonez C, Figueiredo R, Locker D. Predictors of dental care utilization among working poor Canadians. Community Dent Oral Epidemiol. 2009;37(3):199-208. DOI:10.1111/j.16000528.2009.00471.x

12. Mullally BH, Linden GL. The periodontal status of irregular dental attenders. J Clin Periodontol. 1994;21(8):544-8. DOI:10.1111/j.1600-051X.1994. tb01171.x

13. Pinheiro RS, Viacava F, Travassos C, Brito AS. Gênero, morbidade, acesso e utilização de serviços de saúde no Brasil. Cienc Saude Coletiva. 2002;7(4):407-18. DOI:10.1590/S1413-81232002000400007

14. Pinto RS, Matos DL, Loyola Filho Al. Características associadas ao uso de serviços odontológicos públicos pela população adulta brasileira. Cienc Saude Coletiva. 2012;17(2):532-44. DOI:10.1590/S141381232012000200026

15. Pinto VG. Saúde bucal coletiva. São Paulo: Editora Santos; 2000.

16. Sanders AE, Slade GD, Lim S, Reisine S. Impact of oral disease on quality of life in the US and Australian populations. Community Dent Oral Epidemiol. 2009;37(2):171-81. DOI:10.1111/j.16000528.2008.00457.x

17. Shinkay RSA, Cury AADB. O papel da odontologia na equipe interdisciplinar: contribuindo para atenção integral ao idoso. Cad Saude Publica. 2000;16(4):1099-109. DOI:10.1590/S0102$311 \times 2000000400028$

18. Thomson WM, Willians SM, Broadbent JM, Poulton $\mathrm{R}$, Locker D. Long-term dental visiting patterns and adult oral health. J Dent Res. 2010;89(3):307-11. DOI:10.1177/0022034509356779

\footnotetext{
Study performed within the Project to Develop Operational and Management Techniques of Health Services in an Intramuncipal Regions of Porto Alegre - Districts of Restinga Extreme-South, in accordance with the Program to Support Institutional Development of the National Unified Health System, agreed to by the Ministry of Health and the Hospital Assocation of Moinhos de Vento, through accord number 06/2008, signed on 17 of November of 2008.

The authors declare no conflict of interests.

This article was modified in 07/08/2012. Corretion of the affiliation: Where it reads: "Luciene Petcov Machado'; Maria Beatriz Junqueira Camargo"; J José Carlos Milanez Jeronymo"'i; Gisele Alsina Nader Bastos" ('Curso de Especialização Saúde da Família. Escola de Gestão em Saúde. Hospital Moinhos de Vento. Porto Alegre, RS, Brasil; "Associação Hospitalar Moinhos de Vento. Porto Alegre, RS, Brasil; "'Programa de Pós-Graduação em Epidemiologia. Universidade Federal de Pelotas. Pelotas, RS, Brasil)". It should read: "Luciene Petcov Machado'; Maria Beatriz Junqueira Camargo"; José Carlos Milanez Jeronymo"II; Gisele Alsina Nader Bastos"II' ('Curso de Especialização Saúde da Família. Escola de Gestao em Saúde. Hospital Moinhos de Vento Porto Alegre, RS, Brasil; "Programa de Pós-Graduação em Epidemiologia. Universidade Federal de Pelotas. Pelotas, RS, Brasil; '"Associação Hospitalar Moinhos de Vento. Porto Alegre, RS, Brasil).
} 